\title{
Oxidative Damage in Cardiac Tissue from Normotensive and Spontaneously Hypertensive Rats: Effect of Ageing
}

\author{
Juliana C. Fantinelli*, Claudia Caldiz*, \\ María Cecilia Álvarez, Carolina D. Garciarena, \\ Gladys E. Chiappe de Cingolani and Susana M. Mosca \\ Centro de Investigaciones Cardiovasculares, \\ Facultad de Ciencias Médicas, \\ Universidad Nacional de La Plata \\ Argentina
}

\section{Introduction}

The spontaneously hypertensive rat (SHR) is a laboratory model of naturally developing hypertension and heart failure that appears to be similar in many aspects to essential hypertension in humans (Trippodo \& Frohlich, 1981). Systolic blood pressure in SHR rapidly increases during 5 to 10 weeks of age and develops cardiac hypertrophy between 9 and 12 weeks of age (Shimamoto et al., 1982). Increasing evidence from different experimental models supports the concept that oxidative stress contributes to the pathogenesis of myocardial hypertrophy and in the process of myocardial remodeling leading to heart failure (Yücel et al., 1998; Lasségue \& Griendling, 2004).

The oxidative stress is the result of an increase of reactive oxygen species (ROS) and/or inadequate antioxidant defense mechanisms. It has been shown that an increase in the activity and expression of myocardial $\mathrm{NAD}(\mathrm{P}) \mathrm{H}$ oxidase (NOX) is the main source of ROS in cardiac hypertrophy (Bendall et al., 2002; Griendling et al., 2000; Xiao et al et al., 2002). However, existing data about the antioxidant status in hypertension are inconsistent. Some studies have shown that the activities of one or more antioxidant enzymes are lower (Ito et al, 1995; Newaz \& Nawal, 1999), higher (Czonka et al., 2000) or without changes (GómezAmores et al., 2006; Girard et al, 2005) compared with normotensive controls. Although the underlying causes of these discrepancies are unknown, it may be possibly due to the use of different hypertension models, animals at different hypertensive stages and/or different experimental preparations.

On the other hand, ROS are thought to be a key mechanism in the aging process (Beckman \& Ames, 1998; Colavitti \& Finkel, 2004; Harman, 1988) and there are arguments that NOX-

* These authors contributed equally to the present work 
derived ROS may lead to cellular senescence (Ago et al., 2010a; Ago et al., 2010b; Imanishi et al., 2005). Thus, lipid peroxidation and oxidative modification of proteins by ROS like peroxynitrite-the product of combination of superoxide $\left(\mathrm{O}_{2}^{-} \cdot\right)$ and nitric oxide (NO)- are implicated in the pathogenesis of hypertrophy (Nadruz et al., 2004) and in cardiac normal aging (Beal, 2002).

The aim of this study was to assess the oxidative stress in hearts from young and old SHR compared to age-matched Wistar rats.

\section{Methods}

Experiments were conducted with 40 days and 4-, 11- and 19-month-old male SHR and agematched Wistar rats. All animals were identically housed under controlled lighting (12 hs) and temperature $\left(20^{\circ} \mathrm{C}\right)$ conditions with free access to standard rat chow and tap water. The experiments were conducted in accordance with the Guide for the Care and Use of Laboratory Animals published by the US National Institutes of Health (NIH Publication No. 85-23, revised in 1996). Systolic blood pressure (SBP) was recorded by the tail-cuff method (Camilión de Hurtado et al., 2002). Left ventricular hypertrophy (LVH) was evaluated by the ratio between heart weight (HW) and tibia length (TL) as previously described (Yin et al., 1982). Wistar strain was used as normotensive control rat. For the biochemical determinations SHR and Wistar rats of 4- and 19 months-old were used. The animals were decapitated and hearts were quickly removed and perfused with ice-cold saline solution $(0.9 \% \mathrm{NaCl})$ to remove the blood. Left ventricle $(\mathrm{LV})$ samples were taken to assay NOX activity, superoxide production and protein nitration. The rest of the heart was homogenized in 5 volume of $25 \mathrm{mM} \mathrm{PO}_{4} \mathrm{KH}_{2}-140 \mathrm{mM} \mathrm{ClK}$ at $\mathrm{pH}=7.4$ containing protease inhibitors cocktail (Complete Mini Roche) with a Polytron homogenizer. An aliquot of heart homogenate was used to assess lipid peroxidation. The remaining homogenate was centrifuged at $12000 \times \mathrm{g}$ for $5 \mathrm{~min}$ at $4^{\circ} \mathrm{C}$ and the supernatant stored at $-70{ }^{\circ} \mathrm{C}$ until superoxide dismutase (SOD), catalase (CAT) and glutathione peroxidase (GPx) activities were assayed. Protein concentration was evaluated by Bradford method (Bradford, 1976) using bovine serum albumin as a standard.

\subsection{Assessment of lipid peroxidation}

Lipid peroxidation was determined by measuring the level of thiobarbituric acid reactive substances (TBARS), expressed as $\mathrm{nmol} / \mathrm{mg}$ protein. Heart homogenates were centrifuged at $2000 \times \mathrm{g}$ for $10 \mathrm{~min}$. Supernatants $(0.5 \mathrm{ml})$ were mixed with $1.5 \mathrm{ml}$ trichloroacetic acid (30 $\% \mathrm{w} / \mathrm{v}), 1 \mathrm{ml}$ thiobarbituric acid $(0.7 \% \mathrm{w} / \mathrm{v})$ and $0.5 \mathrm{ml}$ water followed by boiling during 15 min. After cooling, absorbance was determined spectrophotometrically at $535 \mathrm{~nm}$, using a $\varepsilon$ value of $1.56 \times 10^{5} \mathrm{M}^{-1} \mathrm{~cm}^{-1}$ (Buege \& Aust, 1978).

\subsection{Assessment of protein nitration}

The interaction of peroxynitrite leads to nitrotyrosine formation actually considered as an indirect marker of oxidative /nitrosative stress (Halliwell, 1997). Thus, we assessed nitrotyrosine level by Western blot analysis. A sample of left ventricle was homogenized in lysis buffer ( $300 \mathrm{mM}$ sucrose; $1 \mathrm{mM}$ DTT; $4 \mathrm{mM}$ EGTA, protease inhibitors cocktail: 1 tablet/15 $\mathrm{ml}$ of buffer; $20 \mathrm{mM}$ Tris- $\mathrm{HCl}, \mathrm{pH}$ 7.4). After a brief centrifugation proteins were 
denatured and equal amounts of protein subjected to PAGE and electrotransferred to PVDF membranes. Membranes were incubated with an anti-nitrotyrosine polyclonal antibody (Cayman Chemical). A peroxidase-conjugated, anti-rabbit IgG (Santa Cruz Biotechnology) was used as secondary antibody, and finally bands were visualized with ECL-Plus chemiluminescence detection system (Amersham). Autoradiograms were analyzed by densitometric analysis (Scion Image).

\subsection{Determination of NAD(P)H oxidase (NOX) activity}

Left ventricular slices (LVS, $1 \times 5 \mathrm{~mm}, 3-3.5 \mathrm{mg}$ dry weight) were incubated for $5 \mathrm{~min}$ at 37 ${ }^{\circ} \mathrm{C}$ in Krebs-Hepes buffer (in mmol/1: $99 \mathrm{ClNa}, 4.69 \mathrm{ClK}, 1.87 \mathrm{Cl}_{2} \mathrm{Ca}, 1.2 \mathrm{SO}_{4} \mathrm{Mg}, 1.03 \mathrm{~K}_{2} \mathrm{PO}_{4}$, $25 \mathrm{CO}_{3} \mathrm{HNa}, 20$ Hepes, 11.1 glucose) bubbled with $95 \% \mathrm{O}_{2}-5 \% \mathrm{CO}_{2}$ to maintain $\mathrm{pH} 7.4$ and then transferred to glass scintillation vials containing the same buffer with $5 \mu \mathrm{M}$ lucigenin. Chemiluminiscence was assessed at $37^{\circ} \mathrm{C}$ over 15 minutes in a Scintillation counter (Packard 1900 TR) at 1-minute intervals. Vials containing all components without tissue were previously counted and the values were substracted from the chemiluminiscence signals obtained in the presence of LVS. NOX activity was measured in the presence of $100 \mathrm{mM}$ $\mathrm{NAD}(\mathrm{P}) \mathrm{H}$ and expressed as cpm/mg dry weight of LVS (Souza et al., 2002).

\subsection{Measurement of superoxide $\left(\mathrm{O}_{2}^{--}\right)$production}

Superoxide production was measured in LVS with lucigenin-enhanced chemiluminiscence in Krebs-Hepes buffer with $5 \mu \mathrm{M}$ lucigenin (Khan et al., 2004). The chemiluminiscence in arbitrary units (AU) was recorded with a luminometer (Chameleon, Hidex) during 30 seconds each with 4.5 min interval during 30 minutes. $\mathrm{O}_{2^{-}}$. production was expressed as $\mathrm{AU}$ per mg dry weight per minute. To determine the involvement of $\mathrm{NOX}$ in $\mathrm{O}_{2}^{--}$. production, the slices were pretreated during $30 \mathrm{~min}$ with $300 \mu \mathrm{M}$ apocynin.

\subsection{SOD, CAT and GPx activities assays}

SOD activity was determined by inhibition of formazan production (produced by nitroblue tetrazolium (NBT) reduction by superoxide anion) at $\mathrm{pH} 10.2$ and $25^{\circ} \mathrm{C}$. The reaction mixture consists in: $100 \mu \mathrm{M}$ xanthine, $100 \mu \mathrm{M}$ EDTA, $25 \mu \mathrm{M}$ NBT, $50 \mathrm{mM} \mathrm{CO}_{3} \mathrm{Na}_{2}, \mathrm{pH}$ 10.2. The reaction was started by the addition of xanthine oxidase, reading the absorbance at 560 $\mathrm{nm}$ each $30 \mathrm{sec}$ for $5 \mathrm{~min}$ (Beauchamp \& Fridovich, 1971). One unit of SOD assay was defined as the amount of enzymatic protein required to inhibit $50 \%$ of NBT reduction.

CAT activity was determined by the procedure of Aebi (1984). Decrease in absorbance at 240 $\mathrm{nm}$ by the addition of $30 \mathrm{mM} \mathrm{H} \mathrm{H}_{2} \mathrm{O}_{2}$ was monitored each $15 \mathrm{sec}$ and for $30 \mathrm{sec}$. One unit of CAT assay was defined as the amount of the enzyme that decomposed $1 \mu$ mol of $\mathrm{H}_{2} \mathrm{O}_{2}$.

The GPx activity was measured according to Lawrence and Burk method (1976). The assay reaction comprised $50 \mathrm{mM} \mathrm{K} \mathrm{HPO}_{4}$ buffer, $1 \mathrm{mM}$ EDTA, $1 \mathrm{mM} \mathrm{NaN}, 1 \mathrm{mM}$ reduced glutathione, $0.2 \mathrm{mM} \mathrm{NADPH}, 0.25 \mathrm{mM} \mathrm{H}_{2} \mathrm{O}_{2}$ and $1 \mathrm{U} / \mathrm{ml}$ glutathione reductase. $\mathrm{Gpx}$ activity was assayed by following NADPH oxidation at $340 \mathrm{~nm}$, measuring the absorbance each $15 \mathrm{sec}$ for $5 \mathrm{~min}$. The activity was calculated using a molar extinction coefficient for NADPH of $6.2210^{3} \mathrm{M}^{-1} \times \mathrm{cm}^{-1}$ at $340 \mathrm{~nm}$. One unit of the enzyme was represented the decrease of $1 \mu \mathrm{mol}$ of $\mathrm{NADPH} / \mathrm{min}$ under assay conditions. 


\subsection{Statistical analysis}

Data are presented as mean \pm SE. Differences between Wistar and SHR, young and old groups were analyzed using two-way analysis of variance (ANOVA) with the NewmanKeul's post-hoc test used for multiple comparisons among groups, considering $\mathrm{P}<0.05$ as statistically significant.

\section{Results}

Comparing to age-matched $\mathrm{W}$ rats, SBP of SHR was higher at all ages examined. The analysis of the time course of SBP showed that as early as at 40-day-old the SHR exhibited higher SBP values compared to age-matched W rats. At 4-month-old SBP increased more in comparison to the youngest rats and it remained elevated throughout the last stage studied. LVH significantly increased in SHR at 4, 11 and 19-month-old compared to age-matched W rats. Higher values were obtained at 11 and 19-month-old SHR when compared to younger SHR. An increase in LVH was also observed in W rats with aging (11 and 19-month-old) compared to younger rats (Table 1 ).

\begin{tabular}{|c|c|c|c|c|}
\hline & \multicolumn{2}{|c|}{ SHR } & \multicolumn{2}{c|}{ Wistar } \\
\hline & SBP (mmHg) & LVH & SBP (mmHg) & LVH \\
\hline 40 days-old & $154 \pm 5^{*}$ & $2.04 \pm 0.11$ & $115 \pm 5$ & $1.56 \pm 0.15$ \\
\hline 4 months-old & $187 \pm 2^{* \#}$ & $2.72 \pm 0.17^{*}$ & $116 \pm 3$ & $2.05 \pm 0.12$ \\
\hline 11 months-old & $178 \pm 1.5^{* \#}$ & $3.18 \pm 0.23^{* \#}$ & $116 \pm 3$ & $2.56 \pm 0.09 \S$ \\
\hline 19 months-old & $191 \pm 5^{* \#}$ & $3.40 \pm 0.26^{* \#}$ & $107 \pm 6$ & $2.46 \pm 0.04 \S$ \\
\hline
\end{tabular}

Table 1. Values of systolic blood pressure (SBP) and left ventricular hypertrophy (LVH) of SHR and Wistar rats of 40 days and 4, 11 and 19 months-old. * $\mathrm{P}<0.05$ in SHR vs. Wistar; \# $\mathrm{P}<0.05$ in SHR vs. 40-day-old; $\$ \mathrm{P}<0.05$ in Wistar vs.to 40-day-old.

Fig. 1 shows TBARS content in hearts from 4-, and 19-month-old SHR and Wistar rats. In hearts from SHR there was a significantly higher TBARS level of approximately $87 \%$ at 19 month-old compared to age-matched Wistar rats. No differences in TBARS with aging were observed in Wistar rats.

Nitrotyrosine levels from hearts of 4 and 19-month-old Wistar and SHR are depicted in Fig. 2. Immunoblotting assays showed a statistically significant increase of approximately $40 \%$ in nitrotyrosine levels at 19-month-old SHR compared to age-matched Wistar rats. The oldest SHR and Wistar rats exhibited an increase of 200 and $120 \%$, respectively, in nitrotyrosine levels compared to their respective younger group.

Although there were no significant differences in NOX between SHR and Wistar hearts from young animals, an increase in aged rats (approximately 30\% for Wistar and 60\% for SHR) was obtained showing SHR the highest values (Fig. 3).

Similar $\mathrm{O}_{2-}$. production was obtained in hearts from Wistar rats and SHR at 4 months of age, whereas in older animals SHR showed a significantly higher $\mathrm{O}_{2}^{-\cdot}$ production (approximately $170 \%$ ) in comparison with age matched Wistar rats (approximately 70\%) (Fig. 4). Anyway, aged rats produced a higher $\mathrm{O}_{2}^{--}$amount that younger. The addition of the selective NOX inhibitor apocynin decreased $\mathrm{O}_{2}^{-}$. production in hearts of aged SHR and Wistar rats. In 4month-old SHR and Wistar rats $\mathrm{O}_{2}^{-}$. production was lower in the presence of apocynin, but 


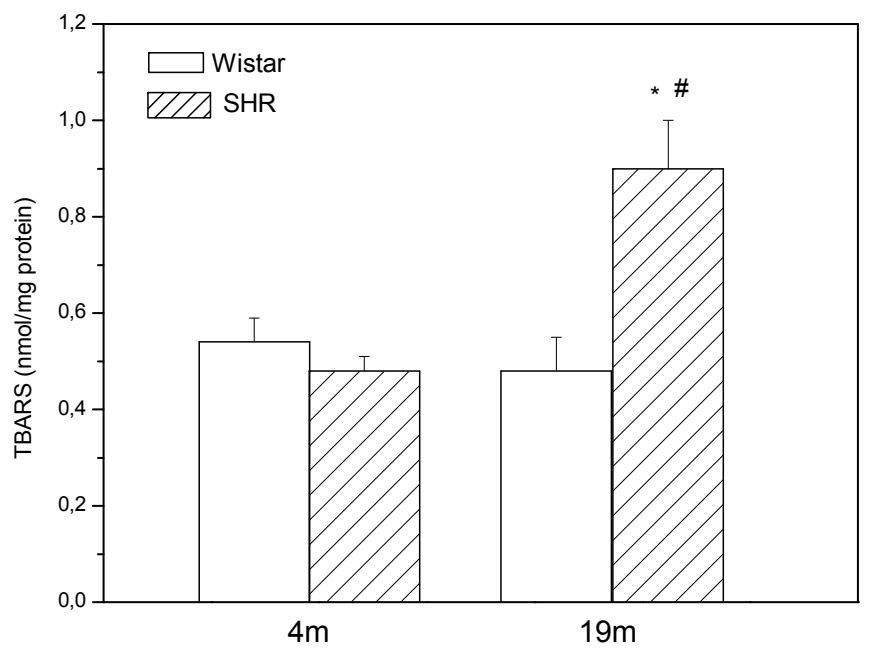

Fig. 1. TBARS content in $\mathrm{nmol} / \mathrm{mg}$ protein, expressed in $\mathrm{nmol} / \mathrm{mg}$ protein in hearts from SHR and Wistar rats at 4, and 19 months-old . ${ }^{*} \mathrm{P}<0.05$ in SHR vs Wistar ; $\mathrm{P}<0.05$ vs 4 months-old SHR.

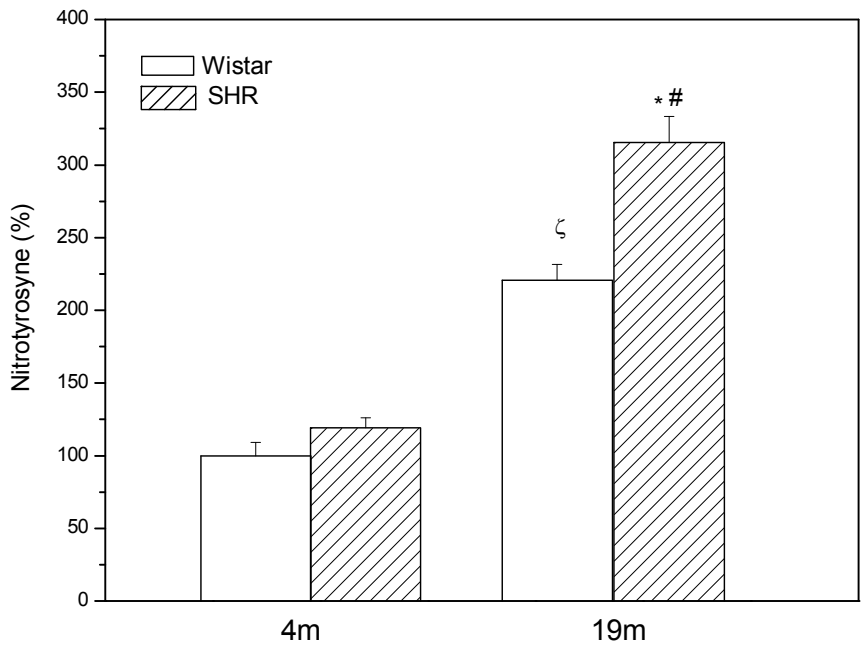

Fig. 2. Nitrotyrosine content, expressed as percentage with respect to 4-month-old Wistar rats in hearts from SHR and Wistar rats at 4 and 19 months-old. ${ }^{*} \mathrm{P}<0.05$ in SHR vs Wistar ; \# $\mathrm{P}<0.05$ vs 4 months-old SHR; ${ }^{\varsigma} \mathrm{P}<0.05$ vs 4 -month-old Wistar rats. 


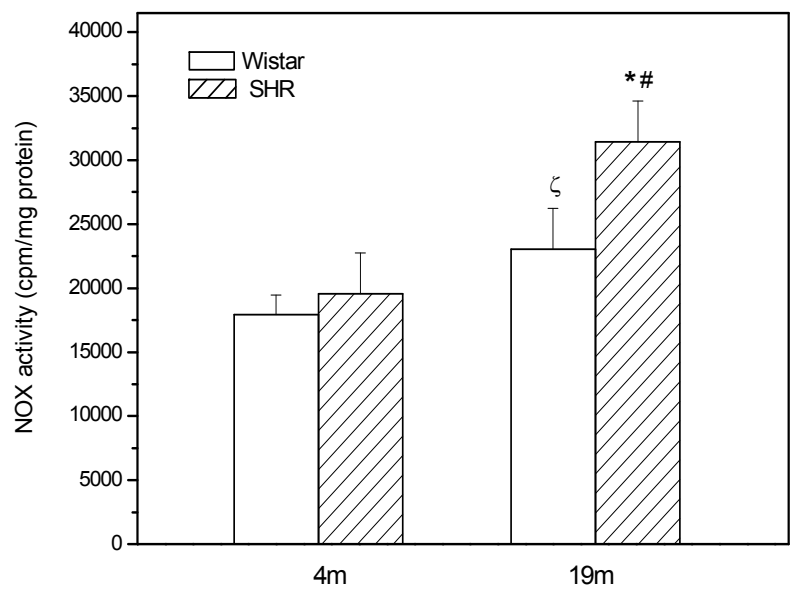

Fig. 3. NOX (NAD $(\mathrm{P}) \mathrm{H}$ oxidase) activity, expressed as $\mathrm{cpm} / \mathrm{mg}$ protein in hearts from $\mathrm{SHR}$ and Wistar rats at 4 and 19-month-old. ${ }^{*} \mathrm{P}<0.05$ in SHR vs Wistar; $\# \mathrm{P}<0.05$ in 19 - vs 4month-old SHR; ${ }^{\varsigma} \mathrm{P}<0.05$ in 19 - vs 4 -month-old Wistar.

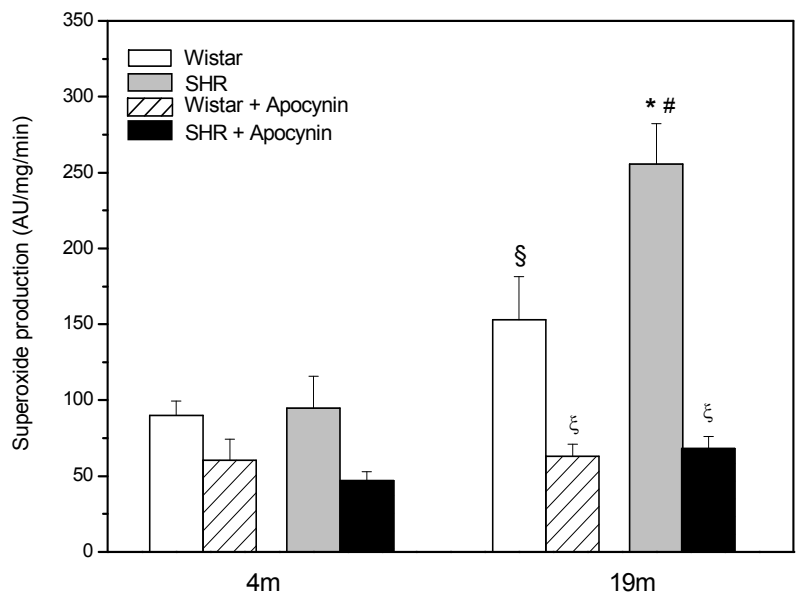

Fig. 4. Superoxide production, expressed as arbitrary units $\mathrm{AU} / \mathrm{mg} / \mathrm{min}$, in hearts from SHR and Wistar rats at 4 and 19 months of age in the absence and presence of apocynin. ${ }^{*} \mathrm{P}<$ 0.05 in SHR vs. Wistar rats, \# P $<0.05$ in 19- vs. 4-month-old SHR, $\$$ P $<0.05$ in 19- vs. 4month-old Wistar rats, $\xi \mathrm{P}<0.05$ in 19-month-old SHR and Wistar rats in the presence vs. absence of apocynin. 
the difference was not statistically significant. This may have been because the lucigenin method was unable to detect very small differences in $\mathrm{O}_{2}{ }^{-}$. levels that were only slightly above the background levels (Dikalov et al., 2007).

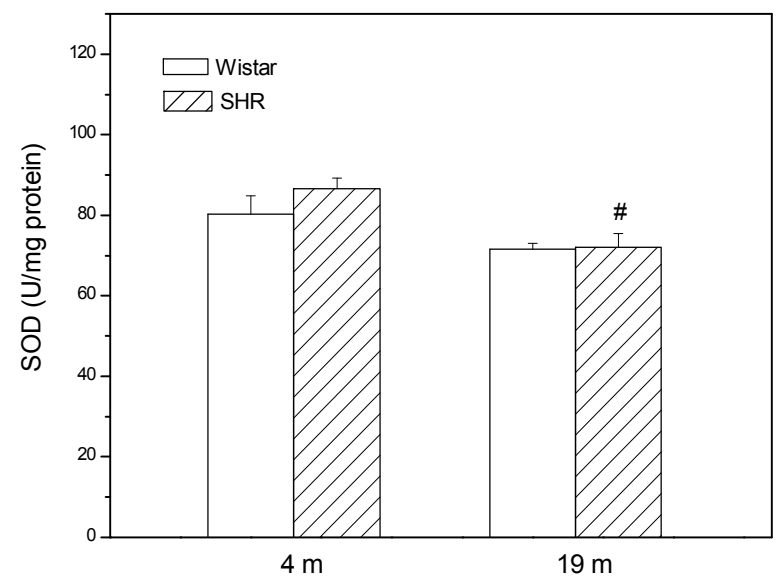

Fig. 5. Superoxide dismutase (SOD) activity, expressed as U/mg protein, in SHR and Wistar hearts of 4 and 19-month-old. \# $\mathrm{P}<0.05$ in 19- vs 4-month-old SHR.

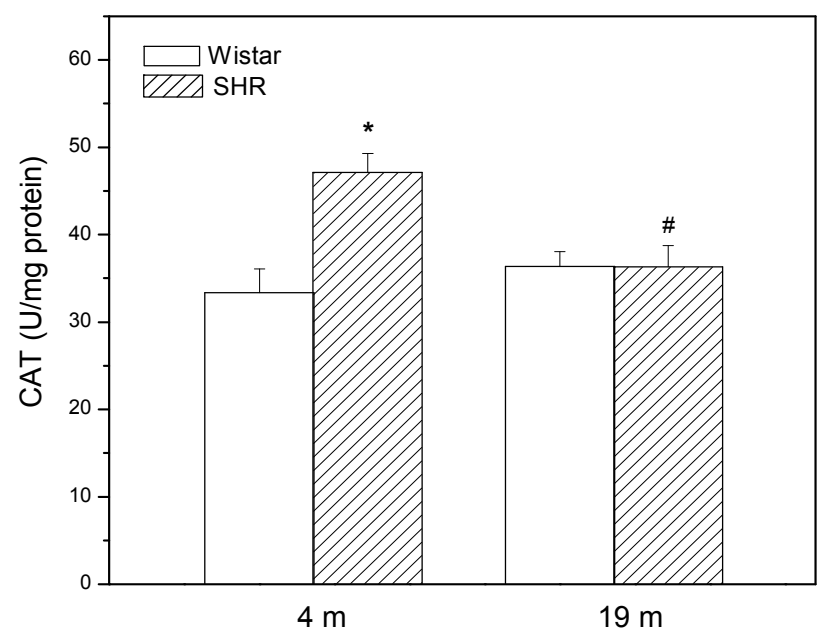

Fig. 6. Catalase (CAT) activity, expressed as U/mg protein, in SHR and Wistar hearts of 4 and 19-month-old. ${ }^{*} \mathrm{P}<0.05$ in SHR vs Wistar ; ${ }^{\mathrm{P}}<0.05$ in 19 - vs 4 -month-old SHR. 
The activities of antioxidant enzymes are shown in Fig. 5, 6 and 7. SOD activity significantly decreased in older hearts from SHR (approximately $17 \%$ ) while not significant differences were detected in Wistar rats with aging (Fig. 5).

Hearts from 4-month-old SHR exhibited a higher catalase activity (approximately 40\%) in comparison to hearts from age-matched Wistar rats and it decreased in 19-month-old SHR. In Wistar rats CAT activity did not change with aging (Fig. 6).

Compared to younger animals, a significant decrease of GPx activity was detected in hearts from 19-month-old SHR and Wistar rats. No differences were detected between SHR and age-matched Wistar rats (Fig. 7).

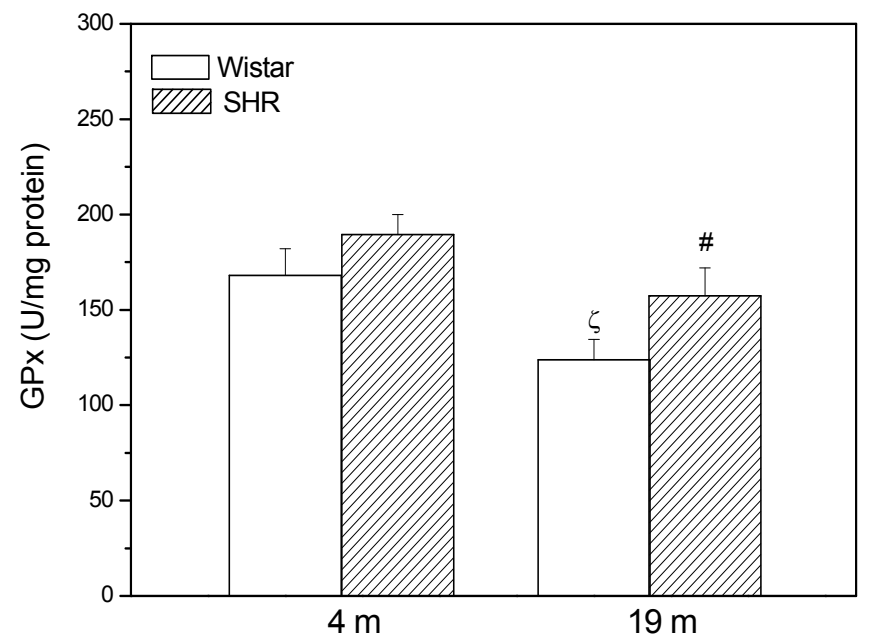

Fig. 7. Glutathione peroxidase (GPx) activity, expressed as $\mathrm{U} / \mathrm{mg}$ protein, in SHR and Wistar hearts of 4 and 19 -month-old. \# $\mathrm{P}<0.05$ in 19 - vs 4 -month-old SHR; ${ }^{\varsigma} \mathrm{P}<0.05$ in 19 vs 4-month-old Wistar.

\section{Discussion}

The present study shows an increase of oxidative stress associated to ageing in both rat strains, showing SHR the highest values. Oxidative stress is a major contributor to the aging process (Fukagawa, 1999) and appears to be a common feature of hypertensive disorders from diverse origins (Ito et al., 1995; Dobrian et al., 2003; Vaziri \& Sica, 2004; Swei et al., 1997). The damage caused by oxidative stress during aging becomes more evident when analyzing the effect of ROS on organic macromolecules, like proteins and lipids. Lipid peroxidation is a major contributor to the age-related loss of membrane fluidity, especially related to increase in the levels of two aldehydic lipid peroxidation products, malonyldialdehyde (MDA) and 4-hydroxy-2-nonenal (HNE). Therefore, it is not surprising that lipid peroxidation is increased in the aged heart as demonstrated by higher levels of 
MDA (Cocco et al., 2005) or HNE (Judge et al., 2005). However, in the present study, in accordance with previously reported data (Muscari et al., 1990; Navarro-Arévalo et al., 1999; Cand \& verdetti, 1989), we did not find any increase of TBARS in hearts from normotensive rats with aging. These results can be explained considering that the normal hearts have a reduced amount of substrate for the lipoperoxidation (Cand \& Verdetti, 1989) or /and the end products of lipoperoxidation are readily metabolized (Muscari et al., 1990) or possess efficient antioxidant defence system . However, we detected an increase in TBARS content with aging in hearts from SHR, compared to age-matched Wistar rats. Moreover, 19-monthold SHR exhibited the highest hypertrophy index and level of lipid peroxidation suggesting that an increase of oxidative damage can be the consequence or the reason for the persistent elevated systolic blood pressure and/or increased cardiac hypertrophy in addition to aging.

Nitric oxide (NO) plays pivotal roles in the maintenance of blood pressure and vascular tone (Loscalzo \& Welch, 1995). Superoxide avidly reacts with NO and in the process produces highly reactive and cytotoxic products, like peroxynitrite (ONOO-). Peroxynitrite, in turn, reacts with and modifies various molecules, namely lipids, DNA, and proteins. For instance, peroxynitrite reacts with the tyrosine and cysteine residues in protein molecules to produce nitrotyrosine and nitrocysteine, leading to inactivation of important antioxidant enzymes, like SOD (Mac Millan-Crow \& Cruthirds, 2001; Alvarez et al., 2004). In addition to these and other harmful biochemical reactions, the oxidation of NO by ROS inevitably results in functional NO deficiency, which can contribute to pathogenesis and maintenance of hypertension and its long-term consequences. In agreement with previous findings in the vasculature of hypertensive animals (Mc Intyre et al., 1999; Zalba et al., 2001), we detected a higher $\mathrm{O}_{2}^{-}$. production in cardiac tissue of aged SHR compared to age-matched normotensive Wistar rats. The fact that blood pressure of SHR decreased with antioxidant therapy implies that oxidative stress is involved in the genesis and/or maintenance of hypertension (Vaziri et al., 2000). Recent investigations using hypertensive models other than SHR have shown that an increase of cellular tolerance to oxidative stress is one of the mechanisms responsible for the efficacy of anti hypertensive treatments such as calcium antagonists (Umemoto et al., 2004; Hirooka et al., 2006), angiotensin II type 1 receptor antagonists, or angiotensin-converting enzyme inhibitors (Takai et al., 2005; Tanaka et al., 2005). In our study, hearts from 4-month-old SHR and Wistar rats showed a similar nitrotyrosine content. In addition to lipid peroxidation data, this result is another demonstration that the higher LVH observed in young SHR relative to age-matched Wistar rats was not accompanied by higher nitrosative damage. Aged Wistar rats exhibited an increase in nitrotyrosilation compared with young animals. This increase was lower in Wistar in comparison to SHR, indicating that the addition of hypertrophy to aging process leads to a high degree of nitration due to an increased imbalance in myocardial production of either $\mathrm{NO}$ or $\mathrm{O}_{2}^{--}$. Although we did not measure the expression or activity of NOS, it has been reported that aged hearts exhibited increased myocardial NOS-cGMP signaling associated with an up-regulation of NOS (Zieman et al., 2001; Llorens et al., 2005). Therefore, higher levels of nitrotyrosine in aged SHR hearts would be attributed to an increase of peroxynitrite derived from an excessive production of both reactive species, $\mathrm{NO}$ and $\mathrm{O}_{2}{ }^{-}$. Another possibility for explaining the higher oxidative and nitrosative stress of aged SHR compared to Wistar rats is a decrease in $\mathrm{NO}$ availability due to an increase in $\mathrm{O}_{2}{ }^{-}$. production. 
Mitochondria occupy a central position in the metabolism of ROS, supporting the so-called "free radical theory of aging" (Beckman \& Ames, 1998; Hardman, 1956; Hardman, 1988). Other cardiovascular sources of ROS include the enzymes xanthine oxidoreductase (Berry \& Hare, 2004), NOX (multisubunit membrane complexes) (Griedling et al., 2000) and eNOS uncoupling (Kuzkaya et al., 2003; Landmesser et al., 2003). This eNOS transformation takes place when its essential cofactor (6R)-5,6,7,8-tetrahydro-L-biopterin (BH4) is oxidized by ONOO- then a functional NOS is converted into a dysfunctional $\mathrm{O}_{2}^{-}$. generating enzyme that contributes to oxidative stress. Abnormal activation and expression of myocardial NOX have been suggested to be the mains sources of ROS in the hypertrophic and failing myocardium (Bendall et al., 2002; Li et al., 2002). A recent paper of Miyagawa et al. (2007) shows that the production of $\mathrm{O}_{2}^{-}$. by NOX in femoral arteries of SHR in comparison to WKY is enhanced, resulting in the inactivation of $\mathrm{NO}$ and impairment of endothelial modulations of vascular contractions. In our study, whereas young SHR showed a similar NOX activity as age-matched Wistar, an increase in the activity of this enzyme was detected in aged SHR, suggesting that NOX-dependent ROS production would be mediating both the hypertrophic response and aging. Apocynin is a well characterized inhibitor of NOX (Meyer \& Schmitt, 2000). It acts by impeding the assembly of the p47-phox and p67-phox subunits within the membrane NOX complex (Meyer \& Schmitt, 2000; Hamilton et al., 2001). Some of the effects of apocynin treatment are protection of the endothelium from the initiating events of atherosclerosis (Hamilton et al., 2001), a reduction of p22-phox mRNA expression and cardiac hypertrophy in aldosterone-infused rats (Park et al., 2004), and a prevention of hyperglycemia-induced intracellular ROS elevation and myocyte dysfunction (Privratsky et al., 2003). Aponycin has also been shown to reduce oxidative stress in stroke-prone spontaneously hypertensive rats, leading to the suppression of cardiac hypertrophy, inflammation and fibrosis (Yamamoto et al., 2006). Under our experimental conditions, apocynin blunted the $\mathrm{O}_{2}^{-}$. production in hearts from aged SHR and Wistar rats. Although a significant increase in NOX activity was only evident in aged SHR hearts, we suggest that NOX-dependent ROS production would mediate both the hypertrophic response and aging.

In the myocardium, as in other tissues, antioxidant enzymes protect cells by maintaining ROS at low levels, thus preventing oxidative damage to biological molecules. SOD rapidly converts $\mathrm{O}_{2}-$ to $\mathrm{H}_{2} \mathrm{O}_{2}$, which is further degraded by CAT and GPx. The levels of the antioxidant enzymes are sensitive to the oxidative stress and increased or decreased levels have been reported in different pathologies in which an enhancement of ROS is cause or consequence of the disease (Navarro-Arévalo et al., 1999; Ulker et al., 2003). Our data show that SOD activity in hearts from young SHR was slightly but not significantly higher than Wistar rats. The lack of significant difference between SOD activities of hearts from both rat strains is in accordance with previous findings (Gómez-Amores et al., 2006; Wilson \& Johnson, 2000; Robin et al., 2004). GPx activity was slightly but no significantly higher in hearts from young SHR compared to age-matched Wistar rats whereas CAT activity showed a significant increase. An opposite result has been recently demonstrated in thoracic aorta of SHR in which a CAT activity decreased and a concomitant increase of $\mathrm{H}_{2} \mathrm{O}_{2}$ were detected (Ulker et al., 2003). Although we did not have experimental evidence, the increase in CAT activity without GPx one changes detected in young SHR would indicate that CAT is acting as compensatory mechanism. This action could lead to a diminution of $\mathrm{H}_{2} \mathrm{O}_{2}$ amount in our preparations and could explain the similar TBARS and nitrotyrosine content obtained in young hearts from both rat strains. Aged Wistar rats did not exhibit any change in SOD and GPx activities. However, a significant diminution of antioxidant enzymes was evident in aged compared to younger SHR. 
These data are in concordance with those reported by Ito et al. (1995) and opposed to recent observations of Csonka et al. (2000). In addition, both rat strains of 19 months old showed similar antioxidant enzyme activity. Therefore, this fact could not explain the differences of oxidative damage detected between aged SHR and $W$ rats. These differences could be attributed to a significantly higher NOX activity in aged than young SHR in accordance with the increased $\mathrm{O}_{2}^{-}$. production with aging, indicating that the compensatory mechanism detected in young rats will be abnormal in cardiac tissue from aged SHR. In this regard, it is worth noting a previous report that an increase of SOD pharmacology potency by lecithinization is able to protect endothelial cells against alterations induced by ROS (Igarashi et al., 1992). Another explanation to the differences observed would be related to angiotensin II content, which appears involved in the genesis of oxidative stress in another tissue than heart in the SHR model (De Godoy \& Rattan, 2006). This hypothesis was supported by the recent experiments performed in vascular tissue of stroke-prone SHR (Takai et al., 2005; Tanaka et al., 2005 ) in which the inhibition of angiotensin receptor or angiotensin-converting enzyme system produced a reduction of ROS production. Our results are also consistent with investigations showing that cardioprotective treatments are mediated by a restoration or up-regulation of antioxidant enzyme (Umemoto et al., 2004; Tanaka et al., 2005). Accumulating evidence has suggested that ROS are capable to activate directly intracellular cascades involved in the regulation of hypertrophic growth (Takano et al., 2003). It has been reported that Rho family proteins, specially Rac1, play critical roles in mechanical stress-induced hypertrophy responses and are involved in ROS-mediated activation of MAP kinases (such as p38, ERK1/2) and activation of nuclear factor- $\mathrm{\kappa B}$. Moreover, Rac 1 is essential for assembly of plasma membrane NOX (Griendling et al., 2000). Thus, in our experimental conditions, sustained hemodynamic load in SHR would modulate the action of extracellular stimuli (such as angiotensin II, norepinephrine, tumor necrosis factor- $\alpha$, epidermal growth factor) on Rac1 activation leading to NOX activation. The increase in $\mathrm{O}_{2}^{-}$- production by NOX would, in presence of a deficient endogenous antioxidant system, activate redox-sensitive kinase cascades and transcription factors. These actions would produce an induction of immediate early genes, reexpression of fetal genes, increased mRNA content and protein synthesis thus leading to the increase in myocyte cross-sectional area and fibrosis observed in aged SHR heart.

\section{Conclusion}

This study shows that an increase in $\mathrm{O}_{2}^{--}$production in NOX dependent way and consequently higher oxidative damage appears associated to the aging process and to the increase in cardiac hypertrophy detected in hearts of SHR compared to age-matched Wistar rats. Thus, oxidative stress would be the cause and/or consequence of hypertrophy development in the SHR model.

\section{Acknowledgement}

This work was supported in part by the grant PICT 1046 from Agencia Nacional de Promoción Científica y Técnica of Argentina to Dr Susana M Mosca.

\section{References}

Aebi, H. (1984). Catalase in Vitro. Methods in Enzymology, Vol. 105, pp. 121-126, ISSN 00766879 . 
Ago, T.; Kuroda, J.; Pain, J.; Fu, C.; Li, H. \& Sadoshima, J. (2010a). Upregulation of Nox4 by hypertrophic stimuli promotes apoptosis and mitochondrial dysfunction in cardiac myocytes. Circulation Research, Vol. 106, No. 7 (April 2010), pp. 1253-64, ISSN 00097330.

Ago, T.; Matsushima, S.; Kuroda, J.; Zablocki, D.; Kitazono, T. \& Sadoshima. J. (2010b). The NADPH oxidase Nox4 and aging in the heart. Aging (Albany NY), Vol. 2, No. 12, (December 2010), pp. 1012-6, ISSN 1945-4589.

Alvarez, B.; Demicheli, V.; Duran, R.; Trujillo, M.; Cervenansky, C.; Freeman, B.A. \& Radi, R. (2004). Inactivation of human $\mathrm{Cu}, \mathrm{Zn}$ superoxide dismutase by peroxynitrite and formation of histidinyl radical. Free Radical Biology \& Medicine,Vol. 37, No. 6 (September 2004), pp. 813-822, ISSN 0891-5849.

Beal, M.F. (2002). Oxidatively modified proteins in aging and disease. Free Radical Biology $\mathcal{E}$ Medicine, Vol. 32, No. 9, (May 2002), pp. 797-803, ISSN 0891-5849.

Beauchamp, Ch. \& Fridovich, I. (1971). Superoxide dismutase: improved assays and an assay applicable to acrylamide gels. Analytical Biochemistry, Vol. 44, No. 1, (November 1971), pp. 276-287, ISSN 0003-2697.

Beckman, K.B. \& Ames, B.N. (1998). The free radical theory of aging matures. Physiological Reviews, Vol. 78, No. 2, (April 1998), pp. 547-581, ISSN 0031-9333.

Bendall, J.K.; Cave, A.C.; Heymes, C.; Gall, N. \& Shah, A.M. (2002). Pivotal role of a gp91(phox)-containing NADPH oxidase in angiotensin II-induced cardiac hypertrophy in mice. Circulation, Vol. 105, No. 3 (January 2002), pp. 293-296, ISSN 0009-7322.

Berry, C.E. \& Hare, J.M. (2004). Xanthine oxidoreductase in the cardiovascular system: molecular mechanisms and pathophysiologic implications. Journal of Physiology, Vol. 555, No. 3, (March 2004), pp. 589-606, ISSN 00219738.

Bradford, M.M. (1976). A rapid and sensitive for the quantitation of microgram quantitites of protein utilizing the principle of protein-dye binding. Analytical Biochemistry, Vol. 72 , (May 1976), pp. 248-254, ISSN 0003-2697.

Buege, J.A. \& Aust, S.D.(1978). Microsomal lipid peroxidation. Methods in Enzymology, Vol. 52, pp. 302-310, ISSN 0076-6879.

Camilión de Hurtado, M.C., Portiansky, E.L., Pérez, N.G., Rebolledo, O.R., Cingolani, H.E. (2002). Regression of cardiomyocyte hypertrophy in SHR following chronic inhibition of the $\mathrm{Na}^{+} / \mathrm{H}^{+}$exchanger. Cardiovascular Research, Vol. 53, No. 4, (March 2002), pp. 862-868, ISSN 0008-6363.

Cand, F. \& Verdetti, J. (1989). Superoxide dismutase, glutathione peroxidase, catalase, and lipid peroxidation in the major organs of the aging rats. Free Radical Biology $\mathcal{E}$ Medicine, Vol. 7, No. 1, (January 1989), pp. 59-63, ISSN 0891-5849.

Cocco, T.; Sgobbo, P.; Clemente, M.; Lopriore, B.; Grattagliano, I.; Di Paola, M. \& Villani, G. (2005). Tissue-specific changes of mitochondrial functions in aged rats: effect of a long-term dietary treatment with $\mathrm{N}$-acetylcysteine. Free Radical Biology $\mathcal{E}$ Medicine, Vol. 38, No. 6, (March 2005), pp. 796-805, ISSN 0891-5849.

Colavitti, R. \& Finkel, T. (2004). Reactive oxygen species as mediators of cellular senescence. International Union of Biochemistry and Molecular Biology (IUBMB) Life, Vol. 57, No. 45, (April-May 2004), pp. 277-281, ISSN 1521-6543.

Csonka, C.; Pataki, T.; Kovacs, P.; Müller, S.L.; Schroeter, M.L.; Tosaki, A. \& Blasig, I.E. (2000). Effects of oxidative stress on the expression of antioxidative defense enzymes in spontaneously hypertensive rat hearts. Free Radical Biology $\mathcal{E}$ Medicine, Vol. 29, No. 7, (October 2000), pp. 612-619, ISSN 0891-5849. 
De Godoy, M.A. \& Rattan, S. (2006). Angiotensin-converting enzyme and angiotensin II receptor subtype 1 inhibitors restitute hypertensive internal anal sphincter in the spontaneously hypertensive rats. Journal of Pharmacology and Experimental Therapeutics, Vol. 318, No. 2, (August 2006), pp. 725-734, ISSN 0022-3565.

Dikalov, S.; Griendling, K.K. \& Harrison, D.G. (2007). Measurement of reactive oxygen species in cardiovascular studies. Hypertension, Vol. 49, No. 4, (April 2007), pp. 717727, ISSN 0194911X.

Dobrian, A.D.; Schriver, S.D.; Lynch, T. \& Prewitt, R.L. (2003). Effect of salt on hypertension and oxidative stress in a rat model of diet-induced obesity. American Journal of Renal Physiology, Vol. 285, No.4, (October 2003), pp. F619-F628, ISSN 1931-857X.

Fukagawa, N.K. (1999). Aging: is oxidative stress a marker or is it causal? Proceedings of Society Experimental BiologyE Medicine, Vol. 222, No. 3, (December 1999), pp. 293298. ISSN 0025.7680.

Girard, A.; Madani, S.; El Boustani, E.S.; Belleville, J. \& Prosa, J. (2005). Changes in lipid metabolism and antioxidant defense status in spontaneously hypertensive rats and Wistar rats fed a diet enriched with fructose and saturated fatty acids. Nutrition, Vol. 21, No. 5, (May 2005), pp. 240-248, ISSN 0899-9007.

Gómez-Amores, L.; Mate, A.; Revilla, E.; Santa-Maria, C. \& Vázquez, C.M. (2006). Antioxidant activity of propionyl-L-carnitine in liver and heart of spontaneously hypertensive rats. Life Sciences, Vol. 78, No. 17, (March 2006), pp. 1945-1952, ISSN 0024-3205.

Griendling, K.K.; Sorescu, D. \& Ushio-Fukai, M. (2000). NAD(P)H oxidase: role in cardiovascular biology and disease. Circulation Research, Vol. 86, No. 5, (March 2000), pp. 494-501, ISSN 0009-7330.

Halliwell, B. (1997). What nitrates tyrosine? Is nitrotyrosine specific as a biomarker of peroxynitrite formation in vivo? FEBS Letter, Vol. 411, No. 2-3 (July 1997), pp. 157160, ISSN 0014-5793.

Hamilton, C.A.; Brosnan, M.J.; McIntyre, M.; Graham, D. \& Dominiczak, A.F. (2001). Superoxide excess in hypertension and aging: a common cause of endothelial dysfunction. Hypertension, Vol. 37, No. 2 Part 2, (February 2001), pp. 529-534, ISSN 0194911X.

Harman, D. (1956). Aging: a theory based on free radical and radiation chemistry. The Journals of Gerontology, Vol. 11, No. 3, (July 1956), pp. 298-300, ISSN 1079-5006.

Harman, D. (1988). Free radicals in aging, Molecular and Cellular Biochemistry, Vol. 84, No. 2, (December 1988), pp. 155-161, ISSN 0300-8177.

Hirooka Y.; Kimura Y.; Nozoe M.; Sagara Y.; Ito K. \& Sunagawa K. (2006). Amlodipineinduced reduction of oxidative stress in the brain is associated with sympathoinhibitory effects in stroke-prone spontaneously hypertensive rats. Hypertension Research, Vol. 29, No.1 (January 2006), pp. 49-56, ISSN 0916-9636.

Igarashi, R.; Hoshino, J.; Takenaga, M.; Kawai, S.; Morizawa, Y.; Yasuda, A.; Otani, M. \& Mizushima, Y. (1992). Lecithinization of superoxide dismutase potentiates its protective effect against Forssman antiserum-induced elevation in guinea pig airway resistance. Journal of Pharmacology and Experimental Therapeutics, Vol. 262, No. 3, (September 1992), pp. 1214-1219, ISSN 0022-3565.

Imanishi, T.; Hano, T. \& Nishio, I. (2005). Estrogen reduces angiotensin II-induced acceleration of senescence in endothelial progenitor cells. Hypertension Research, Vol. 28, No. 3, (March 2005), pp. 263-271, ISSN 0916-9636. 
Ito, H.; Torii, M. \& Suzuki, T. (1995). Decreased superoxide dismutase activity and increased superoxide anion production in cardiac hypertrophy of spontaneously hypertensive rats. Clinical E Experimental Hypertension, Vol. 17, No. 5, (July 1995), pp. 803-816, ISSN 1064-1963.

Judge, S.; Jang, Y.M.; Smith, A.; Hagen, T. \& Leeuwenburgh, C. (2005). Age-associated increases in oxidative stress and antioxidant enzyme activities in cardiac interfibrillar mitochondria: implications for the mitochondrial theory of aging. FASEB Journal, Vol. 19, No. 3, (March 2005), pp. 419-421, ISSN 0892-6638.

Khan, S.A.; Lee, K.; Minhas, K.M.; Gonzalez, D.R.; Raju, S.V.; Tejani, A.D.; Li, D. Berkowitz, D.E. \& Hare, JM. (2004). Neuronal nitric oxide synthase negatively regulates xanthine oxidoreductase inhibition of cardiac excitation-contraction coupling. Proceedings of National Academy of Sciences USA, Vol. 101, No. 45, (November 2004), pp. 15944-15948, ISSN 0027-8424.

Kuzkaya, N.; Weissmann, N.; Harrison, D.G. \& Dikalov, S.(2003). Interactions of peroxynitrite, tetrahydrobiopterin, ascorbic acid, and thiols-implications for uncoupling endothelial nitric-oxide synthase. Journal of Biological Chemistry, Vol. 278, No. 25, (June 2003), pp. 22546-22554, ISSN 0021-9258.

Landmesser, U.; Dikalov, S.; Price, S.R.; McCann, L.; Fukai, T.; Holland, S.M.; Mitch, W.E. \& Harrison D.G.(2003). Oxidation of tetrahydrobiopterin leads to uncoupling of endothelial cell nitric oxide synthase in hypertension. Journal of Clinical Investigation, Vol. 111, No. 8, (April 2003), pp. 1201-1209, ISSN 00219738.

Lassègue, B. \& Griendling, K.K. (2004). Reactive oxygen species in hypertension: An update. American Journal of Hypertension, Vol. 17, No. 9, (September 2004), pp. 852-860, ISSN 0895-7061.

Lawrence, R.A. \& Burk, R.F. (1976). Glutathione peroxidase activity in selenium-deficient rat liver. Biochemical \& Biophysic Research Communication, Vol. 71, No. , (August 1976), pp. 952-958, ISSN 0006-291X.

Li, J.M.; Gall, N.P.; Grieve, D.J.; Chen, M. \& Shah, A.M. (2002). Activation of NAD(P)H oxidase during progression of cardiac hypertrophy to failure. Hypertension, Vol. 40, No. 4, (October 2002), pp. 477-484, ISSN 0194911X.

Llorens, S.; Salazar, F.J. \& Nava, E. (2005). Assessment of the nitric oxide system in the heart, aorta and kidney of aged Wistar-Kyoto and spontaneously hypertensive rats. Journal of Hypertension, Vol. 23, No. 8, (August 2005), pp. 1507-1514, ISSN 0263-6352.

Loscalzo, J. \& Welch, G. (1995). Nitric oxide and its role in the cardiovascular system. Progression Cardiovascular Disease, Vol. 38, No. 2, (September 1995), pp. 87-104, ISSN 0033-0620.

Mac Millan-Crow, L.A. \& Cruthirds, D.L. (2001). Invited review: manganese superoxide dismutase in disease. Free Radical Research, Vol. 34, No. 4, (April 2001), pp. 325-336, ISSN 1071-5762.

McIntyre, M.; Bohr, D.F. \& Dominiczak, A.F. (1999). Endothelial function in hypertension: the role of superoxide anion. Hypertension, Vol. 34, No.4 Pt 1, (October 1999), pp. 539-545, ISSN 0194911X.

Meyer, J.W. \& Schmitt, M.E. (2000).A central role for the endothelial NADPH oxidase in atherosclerosis. FEBS Letter, Vol. 472, No. 1, (April 2000), pp. 1-4, ISSN 0014-5793.

Miyagawa, K.; Ohashi, M.; Yamashita, S.; Kojima, M.; Sato, K.; Ueda, R. \& Dohi, Y. (2007). Increased oxidative stress impairs endothelial modulation of contractions in arteries from spontaneously hypertensive rats. Journal of Hypertension, Vol. 25, No. 2, (February 2007), pp. 415-421, ISSN 0263-6352. 
Muscari, C.; Caldarera, C.M. \& Guarnieri, C. (1990). Age-dependent production of mitochondrial hydrogen peroxide, lipid peroxides and fluorescent pigments in the rat heart. Basic Research of Cardiology, Vol. 85, No. 2, (March-April 1990), pp. 172-178, ISSN 0300-8428.

Nadruz, W.Jr.; Lagosta, V.J.; Moreno, H.Jr.; Coelho, O.R. \& Franchini, K.G. (2004). Simvastatin prevents load-induced protein tyrosine nitration in overloaded hearts. Hypertension, Vol. 43, No. 5, (May 2004), pp. 1060-1066, ISSN 0194-911X.

Navarro-Arévalo, A.; Canavate, C. \& Sánchez-del-Pino, M.J. (1999). Myocardial and skeletal muscle aging and changes in oxidative stress in relationship to rigorous exercise training. Mechanism of Ageing Development, Vol. 108, No. 3, (May 1999), pp. 207-217, ISSN 0047-6374.

Newaz, M.A. \& Nawal, N.N. (1999). Effect of gamma-tocotrienol on blood pressure, lipid peroxidation and total antioxidant status in spontaneously hypertensive rats (SHR). Clinical \& Experimental Hypertension, Vol. 21, No. 8, (November 1999), pp. 12971313, ISSN 0148-3927.

Park, Y.M.; Park, M.Y.; Suh, Y.L. \& Park, J.B. (2004). NAD(P)H oxidase inhibitor prevents blood pressure elevation and cardiovascular hypertrophy in aldosterone-infused rats. Biochemical and Biophysical Research Communications, Vol. 313, No. 3, (January 2004), pp. 812-817, ISSN 0006-291X.

Privratsky, J.R.; Wold, L.E.; Sowers, J.R.; Quinn, M.T. \& Ren, J. (2003). AT1 blockade prevents glucose-induced cardiac dysfunction in ventricular myocytes: role of the AT1 receptor and NADPH oxidase. Hypertension, Vol. 42, No. 2, (August 2003), pp. 206-212, ISSN 0194911X.

Robin, S. ; Courderot-Masuyer, C. ; Nicod, L. ; Jacqueson, A. ; Richert, L. \& Berthelot, A. (2004). Opposite effect of methionine-supplemented diet, a model of hyperhomocysteinemia, on plasma and liver antioxidant status in normotensive and spontaneously hypertensive rats. Journal of Nutrition Biochemistry, Vol. 15, No. 89, (February 2004), pp. 80-89, ISSN 0955-2863.

Shimamoto, N.; Goto, N.; Tanabe, M.; Imamoto, T.; Fujiwara, S. \& Hirata, M. (1982). Myocardial energy metabolism in the hypertrophied hearts of spontaneously hypertensive rats. Basic Research in Cardiology, Vol. 77, No. 4, (July-August 1982), pp. 359-367, ISSN 0300-8428.

Souza, H.P.; Liu, X.; Samouilov, A.; Kuppusamy, P.; Laurindo, F.R. \& Zweier, J.L. (2002). Quantitation of superoxide generation and substrate utilization by vascular $\mathrm{NAD}(\mathrm{P}) \mathrm{H}$ oxidase. Souza American Journal of Physiology Heart and Circulatory Physiology, Vol. 282, No. 2, (February 2002), pp. H466-H474, ISSN 0363-6135.

Swei, A.; Lacy, F.; DeLano, F.A. \& Schmid-Schonbein, G.W. (1997). Oxidative stress in the Dahl hypertensive rat. Hypertension, Vol. 30, No. 6, (December 1997), pp. 1628-1633, ISSN 0194911X.

Takai, S.; Kirimura, K.; Jin, D.; Muramatsu, M.; Yoshikawa, K.; Mino, Y. \& Miyazaki, M.T. (2005). Significance of angiotensin II receptor blocker lipophilicities and their protective effect against vascular remodeling. Hypertension Research, Vol. 28, No. 7, (July 2005), pp. 593-600, ISSN 0916-9636.

Takano, H.; Zou, Y.; Hasegawa, H.; Akazawa, H.; Nagai, T. \& Komuro, I. (2003). Oxidative stress-induced signal transduction pathways in cardiac myocytes: involvement of ROS in heart diseases. Antioxidant ERedox Signaling, Vol. 5, No. 6, (December 2003), pp. 789-794, ISSN 1523-0864. 
Tanaka, M.; Umemoto, S.; Kawahara, S.; Kubo, M.; Itoh, S.; Umeji, K. \& Matsuzaki M. (2005). Angiotensin II type 1 receptor antagonist and angiotensin-converting enzyme inhibitor altered the activation of $\mathrm{Cu} / \mathrm{Zn}$-containing superoxide dismutase in the heart of stroke-prone spontaneously hypertensive rats. Hypertension Research, Vol. 28, No. 1, (January 2005), pp. 67-77, ISSN 0916-9636.

Trippodo, N.C. \& Frohlich, E.D. (1981). Similarities of genetic (spontaneous) hypertension: man and rat. Circulation Research, Vol. 48, No 3. (March 1981), pp. 309-319, ISSN 0009-7330.

Ulker, S.; McMaster, D.; McKeown, P.P. \& Bayraktutan, U. (2003). Impaired activities of antioxidant enzymes elicit endothelial dysfunction in spontaneous hypertensive rats despite enhanced vascular nitric oxide generation. Cardiovascular Research, Vol. 59, No. 2, (August 2003), pp. 488-500, ISSN 0008-6363.

Umemoto, S.; Tanaka, M.; Kawahara, S.; Kubo, M.; Umeji K.; Hashimoto, R. \& Matsuzaki M. (2004). Calcium antagonist reduces oxidative stress by upregulating $\mathrm{Cu} / \mathrm{Zn}$ superoxide dismutase in stroke-prone spontaneously hypertensive rats. Hypertension Research,Vol. 27, No. 11, (November 2004), pp. 877-885, ISSN 0916-9636.

Vaziri, N.D.; Ni, Z. \& Tarnavsky-Hobbs, D.L. (2000). Effect of antioxidant therapy on blood pressure and nitric oxide synthase expression in hypertensive rats. Hypertension, Vol. 36, No. 6, (December 2000), pp. 957-964, ISSN 0194911X.

Vaziri, N.D. \& Sica, D.A. 2004. Lead-induced hypertension: role of oxidative stress. Current of Hypertension Reports , Vol. 6, No. 4, (August 2004), pp. 314-320, ISSN 1522-6417.

Wilson, D.O. \& Johnson, P. (2000). Exercise modulates antioxidant enzyme gene expression in rat myocardium and liver. Journal of Applied Physiology, Vol. 88, No. 5, (May 2000), pp. 1791-1796, ISSN 0021-8987.

Xiao, L.; Pimentel, D.R.; Wang, J.; Singh, K.; Colucci, W.S. \& Sawyer, D.B. (2002). Role of reactive oxygen species and $\mathrm{NAD}(\mathrm{P}) \mathrm{H}$ oxidase in alpha(1)-adrenoceptor signaling in adult rat cardiac myocytes. American Journal of Physiology-Cell Physiology, Vol. 282, No. 4, (April 2002), pp. C926-C934, ISSN 0363-6143.

Yamamoto, E.; Lai, Z.F.; Yamashita, T.; Tanaka, T.; Kataoka, K.; Tokutomi, Y.; Ito, T.; Ogawa, H. \& Kim-Mitsuyama., S. (2006). Enhancement of cardiac oxidative stress by tachycardia and its critical role in cardiac hypertrophy and fibrosis. Journal of Hypertension, Vol. 24, No. 10, (October 2006), pp. 2057-2069, ISSN 0263-6352.

Yin, F.C.; Spurgeon, H.A.; Rakusan, K.; Weisfeldt, M.L. \& Lakatta, E.G. (1982). Use of tibial length to quantify cardiac hypertrophy: application in the aging rat. American Journal of Physiology-Heart and Circulatory Physiology, Vol. 243, No. 6, (December 1982), pp. H941-H947, ISSN 0363-6135.

Yücel, D.; Aydoğdu, S.; Cehreli, S.; Saydam, G.; Canatan, H.; Seneş, M.; Ciğdem Topkaya, B. \& Nebioğlu, S. (1998). Increased oxidative stress in dilated cardiomyopathic heart failure. Clinical Chemistry, Vol. 44, No. 1, (January 1998), pp. 148-154, ISSN 0009-9147.

Zalba, G.; San José, G.; Moreno, M.U.; Fortuno, M.A.; Fortuno, A.; Beaumont, F.J. \& Diez, J. (2001). Oxidative stress in arterial hypertension. Role of $\mathrm{NAD}(\mathrm{P}) \mathrm{H}$ oxidase. Hypertension, Vol. 38, No. 6, (December 2001), pp. 1395-1399, ISSN 0194911X.

Zieman, S.J.; Gerstenblith, G.; Lakatta, E.G.; Rosas, G.O.; Vandegaer, K.; Ricker, K.M. \& Hare J.M.(2001). Upregulation of the nitric oxide-cGMP pathway in aged myocardium: physiological response to l-arginine. Circulation Research, Vol. 88, No. 1, (January 2001), pp. 97-102, ISSN 0009-7300. 


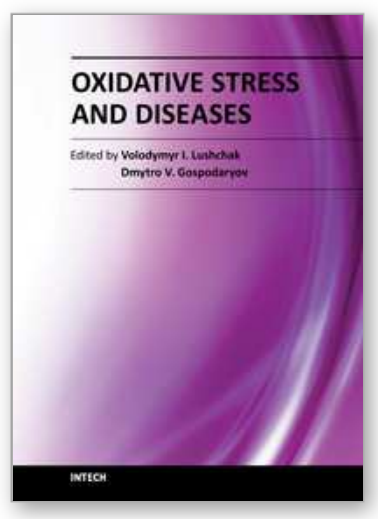

\author{
Oxidative Stress and Diseases \\ Edited by Dr. Volodymyr Lushchak
}

ISBN 978-953-51-0552-7

Hard cover, 610 pages

Publisher InTech

Published online 25, April, 2012

Published in print edition April, 2012

The development of hypothesis of oxidative stress in the 1980s stimulated the interest of biological and biomedical sciences that extends to this day. The contributions in this book provide the reader with the knowledge accumulated to date on the involvement of reactive oxygen species in different pathologies in humans and animals. The chapters are organized into sections based on specific groups of pathologies such as cardiovascular diseases, diabetes, cancer, neuronal, hormonal, and systemic ones. A special section highlights potential of antioxidants to protect organisms against deleterious effects of reactive species. This book should appeal to many researchers, who should find its information useful for advancing their fields.

\title{
How to reference
}

In order to correctly reference this scholarly work, feel free to copy and paste the following:

Juliana C. Fantinelli, Claudia Caldiz, María Cecilia Álvarez, Carolina D. Garciarena, Gladys E. Chiappe de Cingolani and Susana M. Mosca (2012). Oxidative Damage in Cardiac Tissue from Normotensive and Spontaneously Hypertensive Rats: Effect of Ageing, Oxidative Stress and Diseases, Dr. Volodymyr Lushchak (Ed.), ISBN: 978-953-51-0552-7, InTech, Available from: http://www.intechopen.com/books/oxidative-stressand-diseases/oxidative-damage-in-cardiac-tissue-from-normotensive-and-spontaneously-hypertensive-ratseffect-of

\section{INTECH}

open science | open minds

\author{
InTech Europe \\ University Campus STeP Ri \\ Slavka Krautzeka 83/A \\ 51000 Rijeka, Croatia \\ Phone: +385 (51) 770447 \\ Fax: +385 (51) 686166 \\ www.intechopen.com
}

\author{
InTech China \\ Unit 405, Office Block, Hotel Equatorial Shanghai \\ No.65, Yan An Road (West), Shanghai, 200040, China \\ 中国上海市延安西路65号上海国际贵都大饭店办公楼 405 单元 \\ Phone: +86-21-62489820 \\ Fax: $+86-21-62489821$
}


(C) 2012 The Author(s). Licensee IntechOpen. This is an open access article distributed under the terms of the Creative Commons Attribution 3.0 License, which permits unrestricted use, distribution, and reproduction in any medium, provided the original work is properly cited. 